\title{
Nitrite exhaled breath condensate study in patients undergoing cardiopulmonary bypass cardiac
} surgery

\author{
Estudo do nitrito do condensado do exalado pulmonar em pacientes submetidos à cirurgia cardíaca \\ com CEC
}

Viviane dos Santos AUGUSTO ${ }^{1}$, Graziela Saraiva REIS ${ }^{2}$, Verena Kise CAPELLINI ${ }^{3}$, Andrea Carla CELOTTO ${ }^{4}$, Alfredo José RODRIGUES ${ }^{5}$, Paulo Roberto Barbosa EVORA ${ }^{6}$

RBCCV 44205-1240

\begin{abstract}
Resumo
Introdução: Estudos mostrando alterações das concentrações de nitrito ( $\mathrm{NO}_{2}^{-}$) exalado, com biomarcador de lesão, são raros em pacientes submetidos à cirurgia cardíaca. Nesse contexto, o seu estudo no pré e pós-operatório de cirurgias cardíacas poderá contribuir para novos dados clínicos.

Objetivo: O objetivo foi comparar os níveis de nitrito ( $\mathrm{NO}_{2}^{-}$) do condensado do exalado pulmonar (CEP) no pré e pós-operatório de cirurgia cardíaca com circulação extracorpórea.
\end{abstract}

Métodos: Vinte e oito indivíduos foram alocados em três grupos: 1) controle, 2) revascularização do miocárdio e 3) correção valvar. Os níveis de $\mathrm{NO}_{2}-$ foram dosados por quimioluminiscência em amostras de CEP e sangue. Os dados foram analisados pelos testes Mann-Whitney e Wilcoxon.

Resultados: 1) Os níveis de $\mathrm{NO}_{2}$ - no CEP dos grupos 2 e 3 no pré-operatório foram superiores aos do grupo controle; 2) Os níveis de $\mathrm{NO}_{2}$ - no CEP do Grupo 3 foram maiores no

1 - Mestre; Coordenadora do Programa de Aprimoramento em Fisioterapia da Divisão de Cirurgia Cardiotorácica do Hospital das Clínicas de Ribeirão Preto - FMRP/USP.

2 - Mestre; Fisioterapeuta do CTI da Unidade de Emergência do Hospital das Clínicas de Ribeirão Preto - FMRP/USP

3 - Mestre; Pós-graduanda do Departamento de Cirurgia e Anatomia - FMRP/USP.

4 - Professora-doutora;(Coordenadora do Laboratório de Reatividade Vascular de Função Endotelial do Departamento de Cirurgia e Anatomia - FMRP/USP.

5 - Professor-doutor; Docente da Divisão de Cirurgia Torácica e Cardiovascular do Departamento de Cirurgia e Anatomia - FMRP/USP. 6 - Professor Titular; Chefe do Departamento de Cirurgia e Anatomia da FMRP/USP.

This study was done at Department of Surgery and Anatomy, Ribeirão Preto Faculty of Medicine, University of São Paulo, Avenida Bandeirantes, 3900, Ribeirão Preto, São Paulo 14048-900, Brazil. pré que no pós-operatório $24 \mathrm{~h} ; 3$ ) Os níveis de $\mathrm{NO}_{2-}$ plasmático do Grupo 2 foram menores no pré que no pósoperatório $24 h$ e; 4) Não houve diferença na concentração de $\mathrm{NO}_{2}$ - plasmático entre os grupos 2 e 3 no pré-operatório.

Conclusão: Esses dados sugerem que a dosagem de $\mathrm{NO}_{2}$ no CEP é viável em pacientes submetidos à cirurgia cardíaca.

Descritores: Nitritos. Óxido Nítrico. Testes de Função Respiratória. Cirurgia Torácica. Procedimentos Cirúrgicos Cardíacos.

\section{Abstract}

Background: There is a relative lack of studies on postoperative changes in nitrite $\left(\mathrm{NO}_{2}^{-}\right)$concentrations, a marker of injury, following cardiac surgery. In this context, investigations on how exhaled NO concentrations vary in the postoperative period of cardiac surgery will certainly contribute to new clinical findings.

\section{Correspondence address:}

Paulo Roberto Barbosa Evora. Rua Rui Barbosa, 367/15. CEP: 14015120 - Ribeirão Preto, SP, Brazil.

E-mail: prbevora@fmrp.usp.br

This study was supported by Fundação de Amparo à Pesquisa do Estado de São Paulo (FAPESP) and Fundação de Apoio ao Ensino, Pesquisa e Assistência do Hospital das Clínicas da Faculdade de Medicina de Ribeirão Preto da Universidade de São Paulo (FAEPA/HCFMRP/ USP), SP, Brazil. 
Objective: The objective of this study was to compare the EBC NO levels in both the pre and postoperative ( 24 hours) periods of cardiac surgery.

Methods: Twenty-eight individuals were divided into three groups: 1) control, 2) coronary artery bypass grafting, and 3) valve surgery. The nitrite $\left(\mathrm{NO}_{2}^{-}\right)$levels were measured by chemiluminescence in blood samples and exhaled breath condensate (EBC). Data were analyzed by the Mann-Whitney and Wilcoxon tests.

Results: 1) Preoperatively, the $\mathrm{EBC} \mathrm{NO}$ - levels from groups 2 and 3 patients were higher than control individuals; 2) The

\section{INTRODUCTION}

Exhaled nitric oxide (NO) has been considered a potential biomarker of lung injury after cardiac surgery with cardiopulmonary bypass (CPB) [1]. The measurement of pulmonary vasoreactivity is important not only in ischemiareperfusion, but also in patients with pulmonary hypertension, sepsis, and acute respiratory distress syndrome [2].

Bronchoscopy has long been employed for collection of fluid from the lower respiratory tract. However, the invasive nature of this technique has prompted growing interest in the use of exhaled breath condensate (EBC), a simple, safe, and non-invasive approach to the sampling of the lower airways $[3,4]$. Nonetheless, the dosing technique is not well established yet, and the use of multiple devices makes comparison of different studies difficult [5].

There is a relative lack of studies on postoperative changes in nitrite $\left(\mathrm{NO}_{2}^{-}\right)$concentrations, a marker of injury, following cardiac surgery. In this context, investigations on how exhaled NO concentrations vary in the postoperative period of cardiac surgery will certainly contribute to new clinical findings. It is worth mentioning that exhaled NO expresses microcirculatory phenomena better than the measurement of $\mathrm{NO}_{2}^{-}$levels in plasma samples collected from the pulmonary artery. Hence, assessment of exhaled NO may be more representative of vasoreactivity in the case of pulmonary hypertension.

The objective of this study was to compare the EBC NO levels in both the pre and postoperative ( 24 hours) periods of cardiac surgery.

\section{METHODS}

This prospective, nonrandomized study was approved by the Ethics Committee of the Hospital of the Faculty of Medicine of Ribeirão Preto, University of São Paulo (USP).

Twenty-eight adult patients of both sexes, aged between postoperative (24 hours) $\mathrm{NO}_{2}$ - levels in the EBC from group 3 patients were lower compared with preoperative values; 3 ) The $\mathrm{NO}_{2}$ - levels in the plasma from group 2 patients were lower in the preoperative compared with the postoperative $(24 \mathrm{~h})$ values and; 4) Preoperatively, there was no difference between groups 2 and 3 in terms of plasma $\mathrm{NO}_{2}$ - concentrations.

Conclusion: These data suggest that NO measurement in $\mathrm{EBC}$ is feasible in cardiac surgery patients.

Descriptors: Nitrites. Nitric Oxide. Respiratory Function Tests. Thoracic Surgery. Cardiaca Surgical Procedures.
26 and 71 years, were selected for this study and divided into three groups: 1) Control, consisting of 14 healthy volunteers who were not taking any medicine, including smokers, former smokers, and nonsmokers; 2) seven coronary artery bypass grafting (CABG) patients; and 3) seven heart valve surgery patients.

The EBC collector device was mounted in polystyrene box, and a mouth adaptor was added to the circuit, in order to aid patients in breathing in the tidal volume (TV). After correct placement of each circuit (mouth adaptor, plastic tubes, and Eppendorf/1.5 mL), the plastic box was performed with dry ice and positioned in the center of the polystyrene box which was filled with crushed ice. Care was taken so as not to allow direct contact between the two types of ice, and the measured temperature was around $-10^{\circ} \mathrm{C}$.

Room air breathing volunteers were asked to rinse their mouth prior to EBC collection, to minimize saliva contamination. They were instructed to breathe in the TV through the piece adapted to the mouth by closing the lips around it. A calm respiratory pattern was requested during sampling, which lasted 10 minutes. EBC collection in the surgical group occurred at the following moments: a) Preoperatively: preoperative spontaneously breathing patients, and b) Postoperatively: spontaneously breathing patients 24 hours after the end of the CPB surgery. The EBC samples were stored at $-70^{\circ} \mathrm{C}$ until NO dosage using the NO/ozone chemiluminescence method (Sievers NOA 280i, Sievers, Boulder, CO, USA).

Disinfection of devices and materials was accomplished with water and neutral liquid detergent Extran $\mathrm{MaO}_{2}$ (Merck), followed by rinsing with tap water and Milli-Q water, and drying with medical grade compressed air.

For measurement of plasma $\mathrm{NO}_{2}^{-}$levels, $1.5 \mathrm{~mL}$ blood samples were collected through a peripheral venous access preoperatively, and through a central venous access postoperatively. The blood sample was placed in a standard collection tube (BD Vacutainer K2 EDTA) containing 0.08 $\mathrm{mL}$ heparin, transported on ice $\left(-20^{\circ} \mathrm{C}\right)$, and centrifuged at 
$5000 \mathrm{rpm}$ for 10 minutes, at $4^{\circ} \mathrm{C}$. The plasma was deproteinated and stored at $-70^{\circ} \mathrm{C}$ for later $\mathrm{NO}_{2}^{-}$level measurement by NO/ozone chemiluminescence.

\section{Statistical analysis}

The parameters were expressed as mean \pm standard deviation, with $\mathrm{N}$ corresponding to the number of patients. Normality of data distribution was tested using the ShapiroWilk test, which gave evidence of lack of normality. Thus, data were analyzed by the Mann-Whitney and Wilcoxon non-parametric tests, by means of the Prism 4.0 software. Statistical significance was set at $P<0.05$.

\section{RESULTS}

The preoperative NO levels $(4.28 \pm 3.42)$ in the EBC from surgical patients, were higher than those measured in the EBC from the control group $(1.34 \pm 1.34)(P=0.0065)$ (Figure 1). In the case of valve disease, the preoperative EBC NO values were significantly higher than the postoperative levels $(5.26 \pm 4.52$ and $0.70 \pm 0.6$, respectively; $P=0.0173$ ) (Figure 2).

In the surgical group who underwent $\mathrm{CABG}$, there was no statistical difference $(P=0.3095)$ between the preoperative $(3.74 \pm 3.09)$ and postoperative $(2.73 \pm 4.66)$ EBC NOvalues (Figure 3).

There were no significant differences in the preoperative plasma $\mathrm{NO}_{2}{ }^{-}$concentrations of the three groups $(P=0.5031)$. Indeed, similar values were detected in the control group $(0.17 \pm 0.13)$ and preoperative CABG patients $(0.18 \pm 0.11)$, whereas only slightly higher levels were found in the preoperative valve patients $(0.25 \pm 0.16)$ compared with the other groups (Figure 4).

Pre $(0.25 \pm 0.16)$ and postoperative $(0.20 \pm 0.19)$ plasma $\mathrm{NO}_{2}{ }^{-}$concentrations in patients submitted to valve surgery were similar $(P=0.6875)$. In the group that underwent $\mathrm{CABG}$, the plasma $\mathrm{NO}_{2}^{-}$concentration significantly increased postoperatively (preoperative level $=0.18 \pm 0.11$, postoperative level $=0.47 \pm 0.55 ; P=0.0156$ ) (Figure 5).
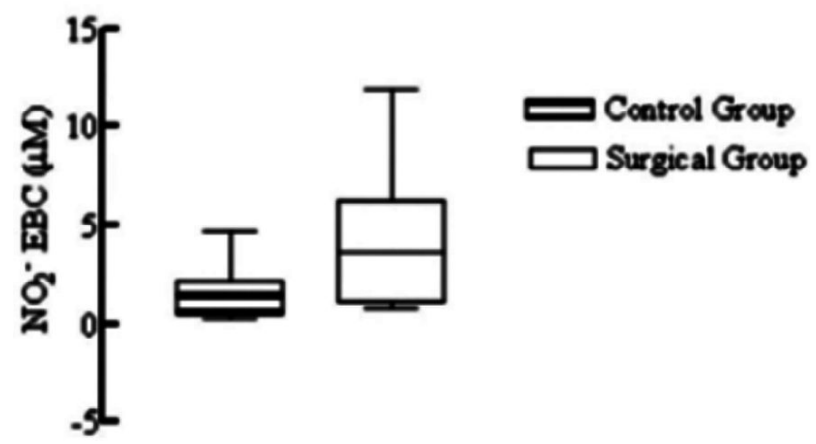

Fig. 1 - Comparison of EBC $\mathrm{NO}_{2}^{-}$levels in the pre-operative period and control group

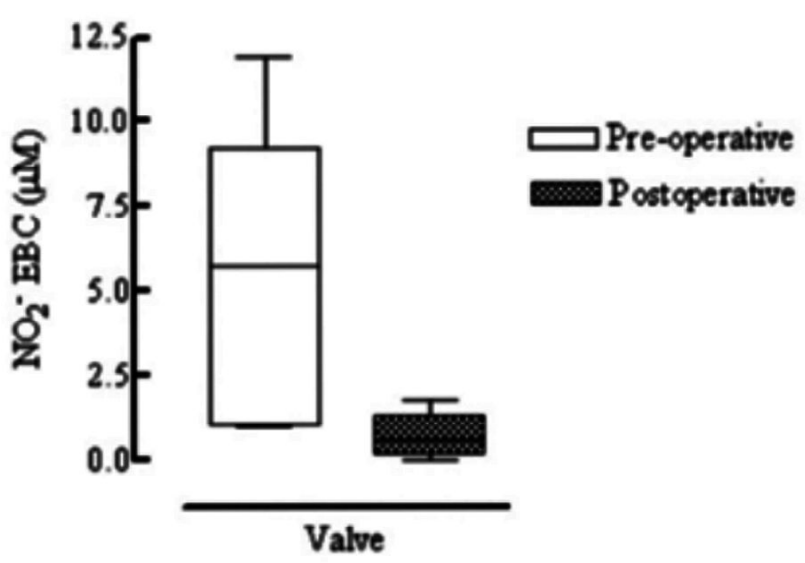

Fig. 2 - Levels of $\mathrm{NO}_{2}-\mathrm{EBC}$ in the pre-operative mitral valve disease and postoperative 24 hours

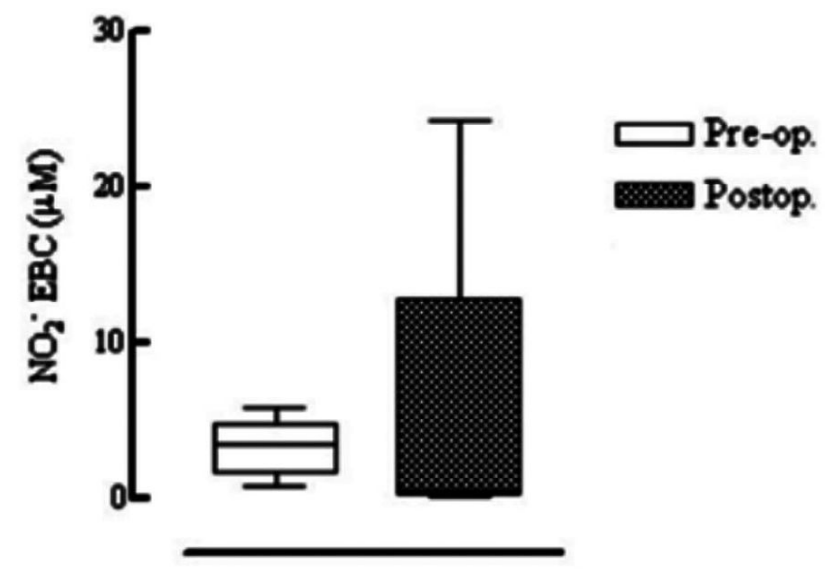

Coronary artery bypass grafting

Fig 3 - Levels of $\mathrm{NO}_{2}^{-}$EBC in the pre-operative and postoperative 24 hours of coronary artery bypass

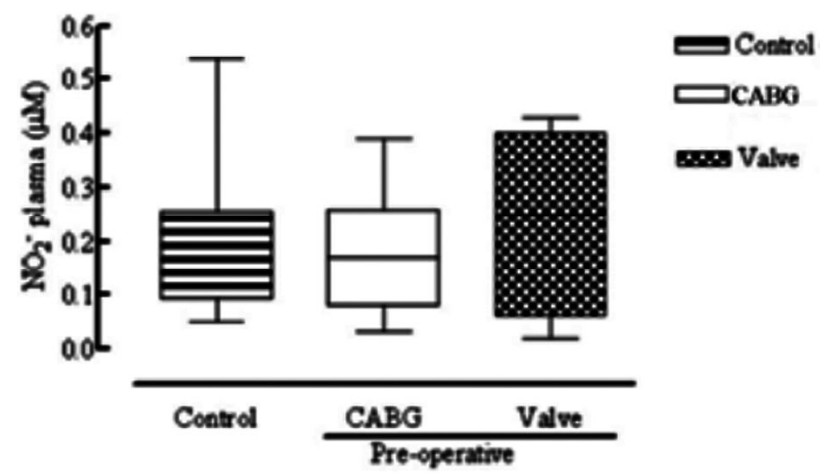

Fig. 4 - Concentrations of $\mathrm{NO}_{2}^{-}$plasma comparing the three groups (control group, preoperative myocardial revascularization and preoperative valve surgery 


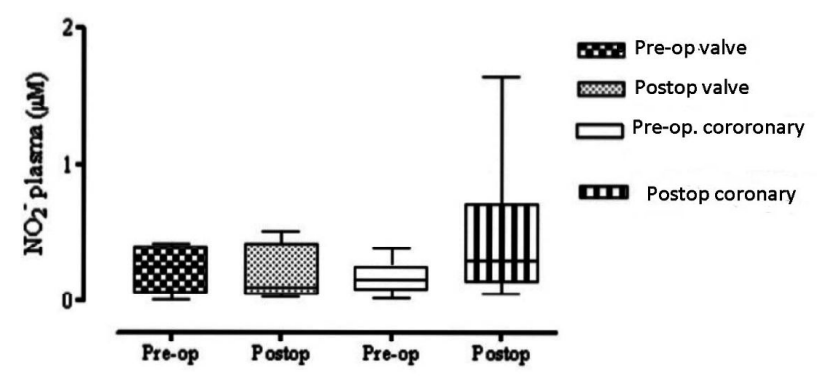

Fig. 5 - Concentrations of $\mathrm{NO}_{2}$ - plasma in the pre and postoperative 24 hours of valve surgery and myocardial revascularization

\section{DISCUSSION}

After CPB cardiac surgery, patients may develop an inflammatory response with increased release of proinflammatory cytokines and NO [6]. Indeed, recent studies have considered NO as an important biomarker of lung injury after cardiac surgery $[1,7]$.

NO concentrations in exhaled air are lower after lung transplantation and in patients with acute respiratory distress syndrome. However, results concerning exhaled NO have only recently been recognized in the case of cardiac surgery patients $[1,7,8]$. The inflammatory reactions induced by CPB are related to the post-CPB period, and these reactions lead to respiratory dysfunction associated with reperfusion syndrome. They also cause interstitial edema, impaired microcirculation of organs due to increased protease activity, free radical production derived partly from granulocytes, and reduced endogenous NO production.

In the present study, significantly higher EBC NO concentrations were detected in cardiac surgery patients preoperatively, compared with healthy individuals (control). In the studied population, $43 \%$ of the surgical volunteers were using drugs such as angiotensin-converting enzyme (ACE) inhibitor (enalapril) and/or isosorbide dinitrate (NO donor). The biochemical and pharmacological effects of $\mathrm{NO}_{3}^{-}$are identical to those of the $\mathrm{NO}$-derived relaxing factor from the endothelium; therefore, isosorbide dinitrate may promote NO bioavailability. According to Sumino et al. [9], because the measurement of exhaled NO is directly derived from the lung, it is possible that ACE inhibitors cause larger NO release in the latter organ compared with the serum $\mathrm{NO}_{\mathrm{x}}$ level in the peripheral venous blood. It is possible that $\mathrm{NO}$ production in the systemic circulation is also promoted by ACE inhibition, but this change is so small that $\mathrm{NO}_{\mathrm{x}}$ is rapidly excreted in urine without apparent alterations in the $\mathrm{NO}_{x}$ serum level. It is thus more advantageous to use the amount of NO measured in expired air as an indicator of the NO level endogenously produced in the lung instead of using the NO serum level.

This is because it is likely that enhanced NO bioavailability induced by ACE inhibition results in larger levels of NO radicals in exhaled air, which is not necessarily accompanied by elevation in $\mathrm{NO}$ metabolites measured as $\mathrm{NO}_{x}$ in the serum. In other words, it is possible that ACE inhibition causes further increase in $\mathrm{NO}$ released by the lungs compared with $\mathrm{NO}_{\mathrm{x}}$ levels present in the plasma from peripheral venous blood. In addition, it can be speculated that the reduced production of angiotensin II and / or the accumulation of bradykinin in the lung tissue may be responsible for the larger NO production in lung components such as the pulmonary vascular endothelium, bronchial epithelial cells, macrophages, and neurons in the nasopharynx [9].

In the present investigation, it was observed that the EBC NO levels decreased, fact that in the case of CABG, or remained close to the preoperative values in the late postoperative period ( 24 hours) of valve surgery. This finding is similar to the results obtained by Kovesi et al. [7], and a possible explanation may be related to the anatomical origin of NO in exhaled air. Although vascular mechanisms contribute to the production of exhaled NO, recent studies suggest that bronchial epithelial cells are those that mostly contribute to NO formation. This is sustained by the distribution of nitric oxide synthase (NOS) isoenzymes in the lungs.

The NOS isoforms iNOS and eNOS are found in the epithelial cells of the airways and produce NO in large quantities. Furthermore, small amounts of NO are produced by NOS type III or eNOS. Thus, the pro-inflammatory cytokines activated after surgery induce high $\mathrm{NO}$ production by iNOS and affect the eNOS expression by destabilizing the ribonucleic acid (mRNA) messenger of this isoenzyme, thereby leading to its lower expression. Although iNOS is quite active during cardiac surgery and the postoperative period, there is no increase in exhaled NO levels because the oxidative stress generated by the surgical procedure causes NO consumption by the superoxide anion, which produces peroxynitrite $\left(\mathrm{OONO}^{-}\right)$[7].

The vascular endothelium is part of an important mechanism that contributes to vasodilation through the endogenous release of prostacyclin and NO. However, the endothelial function may decline with aging. In fact, the vessels appear to be morphologically normal in elder individuals, but a variety of metabolic abnormalities may exist. Although the mechanisms that explain these abnormalities remain unknown, the reduced NO production, increased destruction of NO by superoxide, and changes in membrane flags are compromised [10].

As already mentioned, the inflammatory reactions induced by $\mathrm{CPB}$ are related to the post-CPB period and culminate in respiratory dysfunction, associated with 
perfusion syndrome, causing interstitial edema, renal microcirculation of organs due to increased protease activity, free radical production derived partly from granulocytes, and decreased endogenous NO. In the present study, the plasma $\mathrm{NO}_{2}^{-}$levels in the control group and the preoperative plasma $\mathrm{NO}_{2}{ }^{-}$levels in the $\mathrm{CABG}$ and heart valve surgery patients were similar, with some discrepancy in the values of valve repair patients.

The postoperative plasma $\mathrm{NO}_{2}^{-}$levels of the surgical patients remained virtually unchanged, with the vast majority of surgeries having been performed at $34{ }^{\mathrm{E} \%} \mathrm{C}(11$ patients). These findings differ from those of Ohata et al. [11], who compared mitral valve disease patients submitted to surgery at two different temperatures $\left(28^{\ddot{E} \%} \mathrm{C}, 14\right.$ patients and $34{ }^{\mathrm{E} \%} \mathrm{C}, 17$ patients). Their results indicated that plasma $\mathrm{NO}_{2}{ }^{-}$and $\mathrm{NO}_{3}^{-}$levels, and not the EBC NO levels, increased significantly in the group undergoing surgery at a temperature of $34{ }^{\ddot{\mathrm{E}} \%} \mathrm{C}$, which was accompanied by lowering of systemic vascular resistance. This suggests that the blood temperature is an important factor influencing NO production during cardiac surgery.

Exhaled NO seems to reflect the status of the respiratory system, but it is unclear whether exhaled NO may also be related to the $\mathrm{NO}$ production by the endogenous system. Plasma $\mathrm{NO}_{2}^{-}$and $\mathrm{NO}_{3}^{-}$are stable end products of $\mathrm{NO}$ oxidation, being thus considered specific markers of all the NO formed in the body. Interestingly, some authors have observed augmented synthesis of endogenous NO and elevated plasma $\mathrm{NO}_{2}^{-}$and $\mathrm{NO}_{3}{ }^{-}$concentrations in patients with sepsis syndrome [12].

In the study by Kharitonov et al. [13], administration of L-arginine enhanced both exhaled $\mathrm{NO}$ and plasma $\mathrm{NO}_{3}^{-}$ levels. This phenomenon may suggest a dynamic interplay between total NO production in the body, end products of NO metabolism, and exhaled NO concentrations [13].

Although the exact source of NO production in the airways has not been precisely determined, NO release seems to occur in both upper and lower respiratory tract. Some authors have demonstrated that the majority of exhaled NO is derived from the nose and paranasal sinuses in adults, children, and the newborn [12].

Although the correlation between plasma NO and exhaled NO seems unlikely because of the short half-life of NO in the presence of oxygen, hemoglobin, and reactive oxygen species, it has been shown that NO may be preserved in vivo by binding to albumin and being transported in this form and released elsewhere thereafter [14] In this study, there were no significant correlations between EBC and plasma NO concentrations in the preoperative and postoperative periods of $\mathrm{CABG}$ and valve surgeries. This finding is similar to the results reported by Dillon et al. [15] and Biban et al. [12], who found no correlation between exhaled $\mathrm{NO}$ and plasma $\mathrm{NO}_{2}{ }^{-}$and $\mathrm{NO}_{3}^{-}$ levels. This could indicate that exhaled NO, at least in healthy conditions, is more reflective of local NO release than systemic-derived NO. Nevertheless, it might be argued that exhaled NO is not a representative component of the lung due to contamination of the upper airways (nose and paranasal sinuses) with NO.

\section{CONCLUSIONS}

There is a relative lack of studies in the literature on the use of NO as a marker of lung injury in the postoperative period of cardiac surgery. Thus, studies that demonstrate the importance of NO in the exhaled breath condensate before and after heart surgery will certainly contribute to new clinical findings and may have diagnostic or therapeutic relevance in different clinical situations. Therefore, the following results of this work should be borne in mind:

1) A technique for collection of exhaled pulmonary NO was employed here, which enabled measurement of $\mathrm{NO}$ in exhaled air and was sensitive to changes in $\mathrm{NO}_{\mathrm{x}}$ values, thereby allowing comparison between NO levels in the preoperative and postoperative periods of cardiac surgery $[14,16,17]$.

2) In the preoperative period, the surgical group presented higher NO levels in the exhaled breath condensate compared with the control group. The NO levels in the exhaled breath condensate decreased in the postoperative period in the case of patients undergoing valve repair, whereas plasma $\mathrm{NO}_{2}^{-}$levels increased in the postoperative period ( 24 hours) in the case of coronary artery bypass grafting surgical patients [18];

3 ) In the pre and postoperative ( 24 hours) periods of cardiac surgery, there was no correlation between the exhaled breath condensate NO levels and plasma $\mathrm{NO}_{2}^{-}$levels [18].

\section{REFERENCES}

1. Kövesi T, Szabo A, Royston D, Marczin N. Correlation between pulmonary gas exchange and basal and nitroglycerin (GTN)induced exhaled nitric oxide (eNO) in patients undergoing cardiac sugery. Vascul Pharmacol. 2005;43(6):434-40.

2. Törnberg DC, Angdin M, Settergen G, Liska J, Lundberg JO, Weitzberg E. Exhaled nitric oxide before and after cardiac surgery with cardiopulmonary bypass: response to acetylcholine and nitriglycerin. Br J Anaesth. 2005; 94(2):174-80.

3. Mutlu MG, Garey KW, Robbins RA, Danziger LH, Rubinstein I. Collection and analysis of exhaled breath condensate in humans. Am J Respir Crit Care Med. 2001;164(5):731-7.

4. Liu J, Thomas PS. Exhaled breath condensate as a method of sampling airway nitric oxide and other markers of inflammation. Med Sci Monit. 2005;11(8):MT53-62. 
5. Soyer OU, Dizdar EA, Keskin O, Lilly C, Kalayci O. Comparison of two methods for exhaled breath condensate collection. Allergy. 2006;61(8):1016-8.

6. Mitaka C, Yokoyama K, Morimoto T, Nosaka T, Sunamori M, Imai T. An increase in urinary nitrite/nitrate excretion is associated with the hyperdynamic state after cardiovascular surgery. Intensive Care Med. 2002;28(8):1103-9.

7. Kövesi T, Royston D, Yacoub M, Marczin N. Basal and nitroglycerin-induced exhaled nitric oxide before and after cardiac surgery with cardiopulmonary bypass. Br J Anaesth. 2003;90(5):608-16.

8. Ferreiro CR, Chagas AC, Carvalho MH, Dantas AP, Scavone C, Souza LC, et al. Expression of inducible nitric oxide synthase is increased in patients with heart failure due to ischemic disease. Braz J Med Biol Res. 2004;37(9):1313-20.

9. Sumino H, Nakamura T, Kanda T, Sato K, Sakamaki T, Takahashi $\mathrm{T}$, et al. Effect of enalapril on exhaled nitric oxide in normotensive and hypertensive subjects. Hypertension 2000;36(6):934-40.

10. Levy JH. Management of systemic and pulmonary hypertension. Tex Heart Inst J. 2005;32(4):467-71.

11. Ohata T, Sawa Y, Kadoba K, Kagisaki K, Suzuki K, Matsuda $\mathrm{H}$. Role of nitric oxide in a temperature dependent regulation of systemic vascular resistance in cardiopulmonary bypass. Eur J Cardiothorac Surg. 2000;18(3):342-7.
12. Biban P, Zangardi T, BaraldiE, Dussini N, ChiandettiL, Zacchello F. Mixed exhaled nitric oxide and plasma nitrites and nitrates in newborn infants. Life Sci. 2001;68(25):2789-97.

13. Kharitonov SA, Lubec G, Lubec B, Hjelm M, Barnes PJ. Larginine increases exhaled nitric oxide in normal human subjects. Clin Sci (Lond). 1995;88(2):135-9.

14. Dillon WC, Hampl V, Shultz PJ, Rubins JB, Archer SL. Origins of breath nitric oxide in humans. Chest. 1996;110(4):930-8.

15. Reis GS, Augusto VS, Souza ME, Baldo CF, Rodrigues AJ, Evora PR. Exhaled breath condensate collection for nitrite dosage: a safe and low cost adaptation. Acta Cir Bras. 2010;25(2):206-13.

16. Reis GS, Augusto VS, Souza MEJ, Rodrigues AJ, Evora PRB. Exhaled breath condensate for nitric oxide dosage. A safe and low cost adaptation. Nitric Oxide. 2008;19(Supl):S62.

17. Augusto VS, Reis GS, Souza MEJ, Rodrigues AJ, Evora PRB. A utilização do condensado do exalado pulmonar poderá ser incorporada à rotina de unidades de tratamento intensivo? Rev Bras Ter Intensiva. 2009;21(2):204-11.

18. Augusto VS, Reis GS, Souza MEJ, Rodrigues AJ, Evora PRB. Exhaled breath condensate nitrite and plasma nitrite. Pre-and postoperative comparative study in patients submitted to cardiopulmonary bypass. Nitric Oxide. 2008;19(Supl):S33-4. 